\title{
A INSERÇÃO DOS MIGRANTES ATRAVÉS DAS GERAÇÕES
}

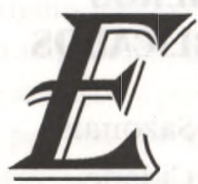
ste número da Travessia, ao tomar como tema as Gerações na Migração, traz à tona a questão das muitas formas de inserção dos migrantes na sociedade de acolhida. É um tema tanto mais atual, que na sociedade européia deste final de século, por exemplo, ele ocupa um lugar prioritário na agenda politica e social. Esta problemática inusitada para os paises do Velho Continente, destaca se no artigo de Neusa, Herbert e Idenilza, quando trata da presença dos filhos de africanos na sociedade portuguesa atual. A questão da inserção passa então pelos relacionamentos de vizinhança, pelas práticas educativas, pela atmosfera de xenofo bia que ronda toda sociedade, pelos dilemas que cada adolescente e sua familia enfrentam no dia a dia.

A inserção dos migrantes também surge como uma problemática nova para os imigrantes brasileiros nos Estados Unidos, como nos mostra Teresa Sales. Ainda na primeira geração, vivendo entre a clandestinidade e uma adaptação funcional, esses brasileiros aos poucos vão se inserindo no novo país e o futuro surge como uma inter rogação, sobretudo a respeito de sua velhice, quando aos poucos vão percebendo que, devido à sua situação irregular, não poderão gozar dos direitos de aposentadoria (para a qual, no entanto, estariam contribuindo).

É no Brasil, porém, através de um olhar retrospectivo para as diferentes gerações de imigrantes que aqui vieram, que é possível observar como esse processo de inser ção foi se realizando. Nos artigos de Zeila, Olga e Samira, tratando respectivamente das gerações nas migrações japonesa, alemã e árabe, percebe se a incidência desse processo no interior das relações familiares, e a importância das mediações no âmbito religioso, associativo, educativo e recreativo. A mutação nas práticas culturais revela como o modo de inserção e integração passa por um processo longo de "negociações" entre a cultura trazida dos paises de origem e a cultura da sociedade de acolhida. As estratégias de inserção envolvem todos os níveis de relacionamento dos imigrantes nas diferentes gerações, e são captados nesses artigos por diferentes métodos, entre os quais destaca -se a História Oral.

Por fim, o artigo de Rosani, de caráter etnográfico, descrevendo as práticas cultu rais desenvolvidas por migrantes nordestinos em torno da Praça Silvio Romero, na cidade de São Paulo, mostra como no interior de uma suposta primeira geração, sur gem visões diferentes da migração, conforme se é migrante "antigo" ou "novo".

\section{Sidnei Marco Dornelas}

